\title{
Stories to (Re)Name By: Relationally Living and Narratively Inquiring Within the Multilayered Midst
}

\author{
Muna Saleh, Jinny Menon, and Hiroko Kubota
}

\begin{abstract}
(Re)telling and (re)living our stories within our response community, we became more wakeful (Greene, 1995) to processes of (re)naming that contoured ways in which we were storied in diverse worlds (Lugones, 1987). We also gained a deeper appreciation as to how we, in turn, (re)named ourselves and others. Narratively inquiring (Clandinin \& Connelly, 2000) into the stories of our names, we autobiographically illuminate our understandings of our (shifting and multiple) selves and experiences and make visible educative possibilities for educators and others looking to compose spaces of mutual care and understanding within the many worlds we co-inhabit.
\end{abstract}

Neither my self nor my narrative can have, therefore, a single strand. I stand at the crossing point of too many social and cultural forces; and, in any case, I am forever on the way. My identity has to be perceived as multiple, even as I strive towards some coherent notion of what is humane and decent and just. (Greene, 1995, p. 1)

As women scholars of color, Maxine Greene's (1995) eloquent words resonate in profound ways. Over three years ago, we shaped a response community (Kubota, Menon, Redlich-Amirav, \& Saleh, 2015; Menon, Redlich-Amirav, Saleh, \& Kubota, 2015) whereby we could attend to our stories of experience as doctoral students and narrative inquirers (Clandinin, 2013; Clandinin \& Connelly, 2000) at various stages in our respective research (Kubota, 2017; Menon, 2015; Saleh, 2017). Within our chosen community (Nelson, 1995), ${ }^{1}$ we sought to tell and retell our experiences from across the temporal continuum and in the many places we compose our lives. Engaging in autobiographical narrative inquiry (Clandinin \& Connelly, 2000; Saleh, Menon, \& Clandinin, 2014) alongside one another, we were often struck by how seemingly innocuous experiences opened up vast fields of inquiry within our response community in which our stories could be (re)viewed "in the light of possibility" (Greene, 1995, p. 22).

As we lived, told, retold, and relived (Clandinin \& Connelly, 2000) our stories, we found ourselves becoming increasingly wakeful (Greene, 1995) to processes of naming and renaming that contoured ways in which we were storied in diverse worlds (Lugones, 1987). ${ }^{2}$ Emboldening upon this concept of wakefulness, we also gained a deeper appreciation as to how we, in turn, named and renamed ourselves and others. In close conversion with each other, we felt that, while our respective experiences with naming and renaming are unique, multiple resonances echoed throughout our stories. What follows is a more detailed account of our storied processes in engaging in this work alongside each other as narrative inquirers and as a response community (Kubota et al., 2015; Menon et al., 2015). 


\section{Our (Relational) Autobiographical Narrative Inquiries}

As both methodology and phenomena, narrative inquiry draws upon a Deweyan (1938) understanding of life as experience and experience as education, alongside the belief that experiences-indeed, lifeare storied constructions (Bruner, 2004; Crites, 1971). Clandinin and Connelly (2000) noted, "Narrative inquiries are always strongly autobiographical. Our research interests come out of our own narratives of experience and shape our narrative inquiry plotlines" (p. 121). Dwelling within metaphorical threedimensional narrative inquiry spaces (Clandinin \& Connelly, 2000; Clandinin, 2013) of temporality (time and continuity), sociality (personal and social relationships), and place (contexts), we engaged in autobiographical narrative inquiries alongside one another within our response community which created spaces whereby we could tell, retell, live, and relive our stories. ${ }^{3}$

Narratively inquiring into the stories of our names, and stories of (re)naming, we share select autobiographical pieces that illuminate myriad understandings of our (multiple) selves and experiences which have shifted and continue to shift alongside others. Embracing our embodied, experiential knowing (Johnson, 1989) in the following sections, we attend to and honor some of the multiple and multilayered personal, familial, intergenerational, social, cultural, linguistic, and interpersonal narratives (Clandinin, 2013) about names that are deeply inscribed in our bodies and minds ... and within which we continue to compose our lives (Bateson, 1989) and identities. With a profound ontological commitment to take care of our stories and each other (Caine et al., 2016; Clandinin, Caine, \& Lessard, in press; Lopez, 1990), we share this deeply relational work in the hopes of illuminating educative (Dewey, 1938) possibilities for educators, community members, and others looking to compose spaces of mutual care and understanding within the many worlds we co-inhabit.

\section{Muna: What's in a Name?}

"Mama ... why did you have to name me Malak?"

Turning to glance at Malak for a moment on the drive to my parents' house, I sighed inwardly. Her query was not a new one. When she first started to ask one of the many variations of this question, I had thought that maybe Malak's discontent with the name I chose for her would subside with time. But this clearly has not happened, since, for over seven years now, she has repeatedly asked the same question. With each query, I am reminded of Juliet's famous musing in Shakespeare's Romeo and Juliet: "What's in a name? That which we call a rose by any other name would smell as sweet" (Shakespeare, trans. 1913, 2.2.47-48). Although I greatly sympathize with Juliet's dilemma, every part of my being tenses at the idea-while eloquently expressed-that a name is not of profound significance.

My name, Muna, is derived from the Arabic word, "wish" —at least this is the closest meaning of my name in the always incomplete travel between languages. My name's meaning lives somewhere in the spaces between longing and desire. Growing up in familial places, my name was everywhere, often sung by famous Arab singers, longingly voiced by Arab actors, and used in reference to similarly monikered 
family and friends in faraway places. At home, I loved what my name signified and was proud that my parents chose such a loving name for me.

The first time I remember wishing (pun intended) that my name was not Muna was on the first day of grade 1. My first-grade teacher was an extremely kind woman and I adored her, but on the first day of school she inadvertently said my name in a way that followed me for a long time. Marking attendance that first day, she called out MOOna. This was a surprise to me as I had never before heard my name pronounced other than the way I had learned to say it. I don't begrudge this lovely woman for this inadvertent error, for my parents, newcomers to the English language, spelled my name on my birth certificate as M-U-N-A. Amidst the snickers that echoed in my ears, I recall putting my shaking hand up very slightly, not wanting the other children to know that MOOna was me. I also remember how Ms. W paused to ask me if she pronounced my name right? I shook my head and croaked out Muna (Munnah). Ms. W bravely attempted to follow my linguistic lead, but the die was already cast. For the next several weeks in class and during recess, I would be besieged with taunts of MOOna and began to despise my name-wishing fervently for a different name, any other name ... one that did not resemble a cow's call.

A few weeks into the school year, Ms. W approached me and apologized for not being able to say my name the way that I do. Her concerned eyes told me that she too heard the taunts. She asked me if it would be okay if she called me Mona from now on. I remember a feeling of elation. Mona was way better than MOOna! It was a normal sounding name, one that would not result in hurtful taunts. Slowly but surely, the name Mona replaced Muna on all of my school supplies and even in school documents. It was only during my undergraduate days that I slowly began introducing myself as Muna again instead of Mona. I am not sure what precipitated this gradual shift, but I know that it was one that gave me a sense of peace, of coming home.

So, what's in a name? For me, my name holds countless roots, giving a sense of personal, familial, cultural, religious, social, and linguistic stories living within me. My name roots and places me. It continues to teach me about my multiple selves and positionings in the different worlds I inhabit and have inhabited growing up. I am drawing upon this knowing when Malak tells me that she wishes I would have named her differently. Why couldn't I have named her something easy like I did with Maya, her baby sister? She says her name sounds too masculine, too harsh, in English. Every time she expresses this I tell her the story of how I had originally planned to name her Hannah-a name that means happiness in Arabic - a name that would allow her to travel with relative ease between the different linguistic worlds she would inhabit as she grows up. I share how that plan changed when I held her for the first time, all seven pounds and two ounces of her, as a 22-year-old young mother who instantly and irrevocably fell in love. Still reeling from a 17-hour labor and delivery, I tell her how I was oblivious to the world around me as I held her, feeling like I was cradling a light from heaven in my arms ... and that is why I decided to name her Malak-a word that means Angel in Arabic. She says she loves this origin story even as she wishes that I would've stuck with my original plan to name her Hannah. I tell her that if she really wants to change her name then I will honor her wishes ... but she always sighs and mumbles, "no, that's okay." After these conversations, I am always left wondering what to do ... will she grow to love her name as much as I do? As much as I have grown to love mine? 
And what of my dear son Ahmad, whose name is not only a linguistic summersault for non-Arabic speakers, but also a clear marker that often translates into "I am Muslim" —in many ways making him just as visible a Muslim as if he had decided to don traditional religious garb. Although Ahmad has never expressed dissatisfaction with his name, one that is honored in Muslim communities because it is a version of the name of the revered Muslim prophet, I consider the story of a man named Salim Zakhrouf who applied to Cathay Pacific for a job as a passenger services officer at Heathrow Airport (Leake, 2011). He was told via email that he had not been selected for an interview. However, applying 48 hours later as "Ian Woodhouse" with an identical CV and home address, he was invited for an interview by the same personnel officer who had emailed the initial refusal.

I am sitting with these considerations as I ponder Malak's question yet again ... and I wonder about the intersections and spaces between parental and child rights, choice, agency, and heritage. I am reminded of Nayyarah Waheed's (2014) short but beautiful poem: "every poem. here. is an unwrite. of all that has been written in me without. permission" (p. 118). And I wonder about my hitherto unquestioned assumption that my children will become strong authors and restoryers of their lives if they are fluent in the stories of their heritage ... who has the right to pen their stories before they learn to author the script of their lives? Are my well-intentioned decisions for them, including their names, another form of imposing stories on them without their permission?

\section{Hiroko: Seeing Myself Again in My Name}

We always start with a name. Before we recognize, we are given names-a name specially given to each of us - which makes us unique and constitutes plurality in the world. Regarding plurality, it is said "plurality is the condition of human action because we are all the same, that is, human, in such a way that nobody is ever the same as anyone else who ever lived, lives, or will live" (Arendt, 1958, p. 8). As it is further mentioned, "Action without a name, a 'who' attached to it, is meaningless" (pp. 180-181). Our unique names symbolically represent the plurality which underpins and guarantees our distinctiveness and interrelatedness with others in the world.

Yet, until recently, I have not paid particular attention to my name. I remember well when I asked my parent about the meaning of my name, my mother awkwardly replied, "It is a girl's name, Hiroko. It doesn't have a specific meaning." The sound of Hiroko was a typical girl's name in Japan a few generations before mine. Usually, each Japanese name is assigned special characters called Kanji to identify its particular pronunciation and meanings. However, the Kanji assigned to my name does not also bear meanings that are instantly appealing to my childhood heart. Since I realized my name did not have a special meaning, I felt less attachment to my name, just regarding it as a labelling to introduce myself.

Now, thinking about my name gives me an increased sensitivity to think about my life again. This one permanent name has continuously been shifting along with time, places, and relationships (Clandinin \& Connelly, 2000). Through reflecting on who called my name and how my name was called in different places at each moment in my life, I could also look back on who I was and how my life has been 
changing. This reflection further encouraged me to see in a new light about how my identity has been transformed with my shifting impressions toward my name. As Carr (1986) elaborated, "We are composing and constantly revising our autobiographies as we go along" (p. 76). I hope this process of recollecting my life through my name would give me different perspectives to (re)tell and (re)live my life.

Hiroko can be divided into two syllables, Hiro-ko. A "ko" suffix means "a child" in Japanese and is normally attached at the end of girl's names. However, in my elementary school, I only found few girls' names ending with "-ko". I did not like my name attached by "-ko" because it sounded out of date. My mother told me that she thought she was going to have a boy and was thinking of a name starting with "Hiro." Because I was a girl, she added "-ko" at the end to shape it as a girl's name. I was always called "Hiro" by my family. Regardless of my discouragement and my innocent wish for a fancy name, I always liked the sound of "Hiro" because it always came with the warm and loving voice of my family.

In Japan, people usually call each other by their last name in formal occasions. After I started working as a nurse in Japan, I was called "Yamane-san," which is a formal way of calling a name in Japan; "san" is a suffix to express respect to others which is similar to "Mr." or "Ms." in English. Whenever patients called me "Yamane-san" in a friendly voice, I was simply happy because I appreciated how they recognized me as a person, not just as a profession. Most patients addressed me as "nurse," that is "kangoshi-san" in Japanese, but I preferred to be called "Yamane-san." Also, I made a concerted effort to call patients by their names to avoid putting them into a category of patients. Calling patients by their names helped me attend closer to them in relational ways which could mitigate their uneasy experiences in an unfamiliar hospital setting. As a nurse, I recognized how important it is to respect patients as individuals, part of which was demonstrated by calling them by their names.

When I was 24 years old, I made a decision to come to Canada to study in the master program in nursing. As this was my first experience living abroad, everything was new to me. I remember I had a strange feeling when people called my name with an unusual accent of "hi-RO-ko." In Japan, my name was pronounced "HI-ro-ko," with less emphasis. I assumed it might be easier for people to say my name with this pronunciation; I even started to introduce my name as "hi-RO-ko." While adjusting myself to my new name and the new environment, I found my identity was also shifting.

For the first few years, I was thinking of adopting an English name as many people kept asking my name again, but I decided not to take away my name. After living in Canada for several years, I came to realize that my name is my home. Living far away from my family, my name has become a mental home to me, which, like a thread, connects me with my cherished memories and relationships. Eventually, my name has built a coherence and foundation on which my stories develop and has become interwoven with my future stories and stories of others. As I got used to the new pronunciation of my name in Canada, I have come to appreciate my name because "Hiroko" represents who I am, my unique identity in Canada. 
After coming to Canada, I met my husband, who was also from Japan, and we married. At the time of marriage, my family name was changed from "Yamane" to "Kubota." It is the common practice in Japan for a woman to take the man's family name after marriage. Although I do not say my last name often in Canada, whenever I introduced myself with my last name to Japanese visitors or wrote down my full name in official documents, I had a feeling of alienation in my name. However, with my new last name, I am grateful that my sense of family has expanded to include my husband's family. For me, changing my last name was a transitional moment in my life; I was surprised how much my new last name changed my impressions of my life.

Although I have been called differently in respective moments, my name stays unchanged like a cornerstone of my life. My name is a gift from my family and is a way of honoring them. My name also signifies connections with people who appeared in my life and who shared their love, protection, teachings, and care with me. Except when introducing ourselves, we do not say our names aloud. Yet, we more often hear others calling our names. When recalling people who lovingly called my name-my grandfather, grandmother, mother, sister, teachers, and friends-I could immediately travel to these loving relationships. "Hiroko, everything will be fine" —l still remember the gentle encouraging voice of my grandfather who passed away five years ago. I strongly wish to be called my name again by him, but it is no longer possible. In the memory, his voice and his compassion will ever stay in my mind and be engraved in my name. As I continue my life, I am sure my name will be continuously called by many people in various ways. I wonder what new journeys my name will take me on in the future and what stories I will tell about my name. Now, I proudly say "Hiroko Kubota" is my name-my important gift and place where my memory and identity will continue to grow. My name embodies itself throughout my body and how I live my life.

\section{Jinny: (De)scribing Names}

Entering the diner, I made my way to the table, aware of pointed glances. And that's when I heard the slurs, Darkie ... Paki. ${ }^{4}$

Growing up with an Indian name in Alberta, it was routine for me to hear my birth name distorted, sometimes with a nod to its "exotic-ness" paired with kindly attempts to pronounce it, which I appreciated. Other mispronunciations were less benign. Huber, Caine, Huber, and Steeves (2013) affirm: "Our very identities as human beings are inextricably linked to the stories we tell of ourselves, both to ourselves and with one another" (p. 214). In my doctoral proposal (Menon, 2015), as I reflected upon my name and the ways in which I named and was, in turn, named, stories of identity, citizenship, home, and (be)longing emerged. I wrote:

As a child and a youth, my name had been the albatross that hung heavy about my neck. It weighed me down and added to the innate differentness of who I was in relation to my peers. It was an indelible reminder, if I needed one, of how I was perceived as not Canadian by some. A Canadian would not have such an odd name. (p. 12)

In elementary school, I learned my name was a jail word-a word that did not follow the spelling rules. Drawing a series of bars, my teacher "imprisoned" my name on the board. 


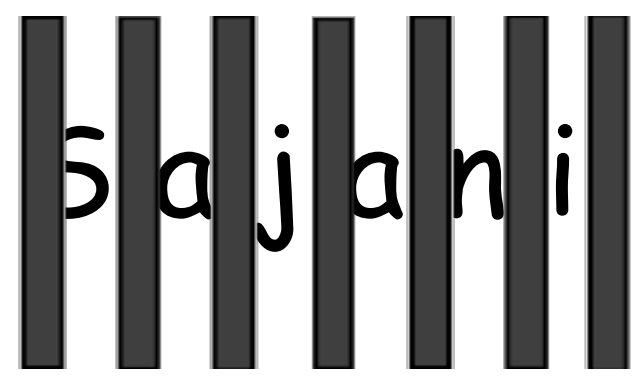

Fig. 1: "Jail girl": "Imprisonment" of my name

This confused me. I wondered what I had done wrong. Fellow students were likewise discombobulated, and I remember being called "Jail Girl" by some classmates. Subsequent grades in the same school had peers mispronouncing my name daily with an agreeable sort of consensus. I got used to it. It was my name, sort of. Even so, when substitute teachers taught class, I dreaded roll call. I could pinpoint when the instructor reached my name on the list. Pausing, no doubt inwardly cursing, he or she would then make for gold. The utterance, typically, a mangled version of my name hurriedly voiced, or the ensuing default, a slow evisceration of it-left me wanting to slide under my desk. Students who accompanied me in previous grades would gallantly call out in chorus to the ruffled teacher, "No, her name is Sajani!" and proffer the now standardized anglicized version of my name.

In Junior High, when a teacher informed me he couldn't say my name and therefore would shorten my name, I was taken aback. Released, from the word jail shaped in elementary school, my freedom seemed short-lived. Even then, I recognized that my name was too foreign for him. Unaware of my angst, my favorite junior high teacher called me Saj throughout the years, encouraging students and other teachers alike to pick up the habit. Again, I felt confusion take root in my thoughts. Who was I in other people's stories of me? Who was I in my own stories?

By the time university rolled around, I thought I had heard all possible distortions of my name. I was wrong! I recall a moment in my undergraduate educational ethics class. I was awaiting my turn to make a presentation, when the instructor called out, "Sir Johnny! Where is Sir Johnny?" Looking about the room in hopes I heard wrong, I realized she meant me. Thrown off-balance, I made my way to the front and mumbled that was not the way to say my name. At her blank look and in the midst of erupting giggles from the class, I rushed through my presentation, thoroughly mortified. Being labelled a male and knighted, albeit unofficially, had not helped my self-esteem.

Completing my Education degree, I moved to Japan to teach English in a town alongside people from the United States, New Zealand, Australia, and England. There too, colleagues struggled with my name. Named by some as gaijin (foreigner in Japanese) and coupled with an "unwieldy" birth name, I had to repeatedly spell and pronounce my name for people. At this point, I figuratively threw up my hands. I dropped the anglicized Sa sound from my name, shortening it to Jinny-which many were already using. 
Everyone found this most agreeable, some even saying, "That's much easier," with me quipping lightly, "For whom?" Named for love and goodness by my mother, I felt a sense of loss, that some part of me had died. This demise was made all the worse when returning home, people who knew me by my birth name queried in horrified tones, "What have you done?" Ascribing meanings to what this name change meant, the belief was that I had "sold out," that I held no pride for my roots. This, of course, was ludicrous. As a child, I hated how my name was distorted and wished for a name which rolled off people's tongues and didn't proclaim me as stranger.

Sharing these storied moments, I closely identify with the words of hooks (1989):

One of the many reasons I chose to write using the pseudonym bell hooks, a family name ... was to construct a writer-identity that would challenge and subdue all impulses leading me away from speech into silence .... I claimed this legacy of defiance, of will, of courage, affirming my link to female ancestors who were bold and daring in their speech. (p. 9)

Gloria Watkins, in scribing bell hooks, discovered freedom in her multiplicities. Similar to hooks, this (re)naming of myself was profound. Sometimes we strive to live up to our names, especially those given to us composed in love, while other times, we try to flee from them when those names harbor ill will. This choice to (de)scribe myself is simultaneously an act of resistance and empowerment. Like my birth name, Jinny, too, is simply and complicatedly, "a new spelling of my name" (Lorde, 1982, Title).

Ruminating upon how names and the processes of naming are indelibly intertwined with the stories that we tell ourselves, the stories we tell others, and the stories others tell of us, I harken back to my current multiperspectival narrative inquiry (Clandinin, 2013) alongside South Asian girls, their mothers, and teacher. ${ }^{5}$ I wonder about the stories which live in them and are lived by them. In our conversations, (un)healthy naming stories alongside stories of being named and of naming have come to light. These stories we have shared, and still others yet, deepen my knowing that names inscribe stories within stories. Clandinin, Caine, Lessard, and Huber (2016) explain, "As we engage in narrative inquiries alongside children and youth, we too become part of these interactions" (p. 97).

Boxer Muhammad Ali, feeling disrespected by his opponent who refused to call Ali by his new name, famously challenged him (Nelson, 2009). In between swings, Ali demanded, "What's my name?" Revisiting the moment when the slurs of Paki and Darkie were spoken, I accept I am a person of many names and that, we all are people of many names. Even as the names I live are plotlines inscribing my former, present, and forward-looking lives, so too are names for others. I think about Muhammed Ali's question, his insistence on respect, and his question's continued relevance today. Yet I wonder too, if we also took time to query of one another, "What's your name?" not merely by means of introduction, but repeatedly, and in different ways, across myriad contexts throughout our relationships, would we be free then, to embrace the humanity in each of us? 


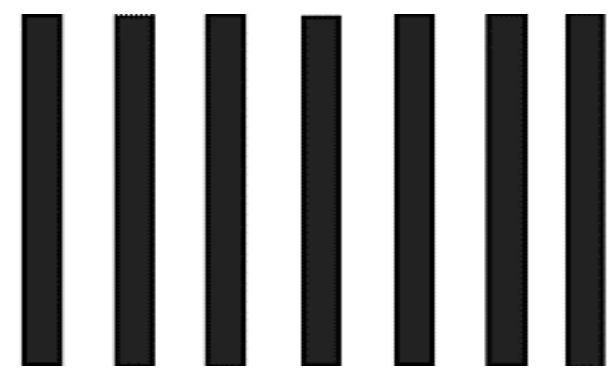

Fig. 2: Freedom to embrace the humanity in each of us

\section{(Re)imagining Possibilities for (Re)naming Ourselves and Others}

Women have always had a particularly close relationship to changeable terrain. In their quest for self knowledge, boundaries, and names, women have found themselves between varying cultural demands .... [however], when recognized, liminality offers women freedom to become themselves. (Heilbrun, 1999, preface 1)

Perhaps inevitably, inquiring into our experiences within our response community involved tensions when different ways of perceiving our experiences bumped up against familiar personal and professional plotlines. These tension-filled moments often made visible for us liminal spaces—spaces characterized by unsteadiness and, simultaneously, possibility (Heilbrun, 1999)—whereby our stories could be (re)imagined alongside one another. As we worked together amidst this uncertainty to attend more closely to the multiplicity of our being and becoming, we also recognized that we are each in the midst of living in relation to multiple personal, social, cultural, linguistic, familial, intergenerational, institutional, and interpersonal (Clandinin, 2013) narratives inextricably intertwined with our everyday lives and experiences.

Over the years, scholars across different disciplines have discussed the significance of names in relation to personal and social identity (Deluzain, 1996), future success (Mehrabian, 1992), likeability (Laham, Koval, \& Alter, 2011), employability (Bertrand \& Mullainathan, 2004; Cotton, O'Neill, \& Griffin, 2008), delinquency (Kalist \& Lee, 2009), and school achievement (van Tilburg \& Igou, 2014), amongst many other areas of study. Our stories, however, foreground how the bestowal of a name can be received in much the same incandescence as a much-treasured gift from an individual or not so happily receivedwhereupon a name is thrust upon a person without her consent and becomes an indelible source of pain. We understand that, in these dynamic processes of naming and renaming, there exists much potential for violence. At the same time, we find there are also just as many possibilities for demonstrably showing care for one another.

Living nuanced and complicated lives, we contend, entails a certain ethical obligation to see all people in their beautiful, messy, (un)easy diversity. Being wakeful (Greene, 1995) permits us to gain a deeper appreciation for the humanity - the sacred humane-that lives in all of us. That is, in this particular instance, being wakeful to how naming stories and the underlying processes of (re)naming ourselves and others have both the power to uplift and the potential to destroy. However, this is an ongoing life 
endeavor, and is in no way an easy work to embody. Yet, as Audre Lorde (1984/2007) movingly conveyed, "The quality of light by which we scrutinize our lives has direct bearing upon the product which we live, and upon the changes which we hope to bring about through those lives" (p. 36). It is our hope that, by illuminating our experiences, we can cocreate invitational spaces for others to actively (re)imagine how the worlds (Lugones, 1987) we construct and inhabit alongside others might be (re)viewed "in the light of possibility" (Greene, 1995, p. 22).

\section{Notes}

1. Drawing upon the work of Marilyn Friedman, Nelson (1995) differentiated between "found" and "chosen" communities by asserting that we are all members of found communities-that is, communities within the places we find ourselves, such as schools, workplaces, and nations. However, Nelson illuminated the transformational possibilities of communities of choice, particularly for women.

2. Lugones (1987) clarified, "a 'world' need not be a construction of a whole society. It may be a construction of a tiny portion of a particular society. It may be inhabited by just a few people. Some "worlds" are bigger than others" (p. 10).

3. Clandinin (2013) explained that

people live out stories and tell stories of their living. Narrative inquirers come alongside participants ... and begin to engage in narrative inquiry into our lived and told stories. We call this process of coming alongside participants and then inquiring into the lived and told stories retelling stories. Because we see that we are changed as we retell our lived and told stories, we may begin to relive [Emphasis added] our stories. (p. 34)

4. A hostile rhetoric towards perceived difference seems to be normalized for some individuals. See: CBC News (2016), for instance.

5. We sincerely thank The Social Sciences and Humanities Research Council of Canada for supporting this research.

\section{References}

Arendt, H. (1958). The human condition. Chicago, IL: The University of Chicago Press.

Bateson, M. C. (1989). Composing a life. New York, NY: A Plume Book.

Bertrand, M., \& Mullainathan, S. (2004). Are Emily and Greg more employable than Lakisha and Jamal? A field experiment on labor market discrimination. American Economic Review, 94(4), 991-1013. doi:10.1257/0002828042002561

Bruner, J. (2004). Life as narrative. Social Research, 71(3), 691-710. Retrieved from http://www.jstor.org/stable/40971721?origin=JSTOR-pdf

Caine, V., Murphy, M. S., Estefan, A., Clandinin, S. J., Steeves, P., \& Huber, J. (2016). Exploring the purposes of fictionalization in narrative inquiry. Qualitative Inquiry, 23(3), 215-221. doi:10.1177/1077800416643997 
Carr, D. (1986). The self and the coherence of life. In Time, narrative, and history: An essay in the philosophy of history (pp. 73-99). Bloomington, IN: Indiana University Press.

CBC News. (2016, November 17). Trump accused of giving 'a shot of adrenalin' to Canadian racists. CBC News. Retrieved from http://www.cbc.ca/news/canada/donald-trump-racist-incidents-canada1.3853681

Clandinin, D. J. (2013). Engaging in narrative inquiry. Walnut Creek, CA: Left Coast Leaf Press.

Clandinin, D. J., Caine, V., \& Lessard, S. (in press). Relational ethics of narrative inquiry.

Clandinin, J., Caine, V., Lessard, S., \& Huber, J. (2016). Engaging in narrative inquiries with children and youth. Taylor and Francis. ProQuest Ebook Central. Retrieved from https://ebookcentral.proquest.com

Clandinin, D. J., \& Connelly, F. M. (2000). Narrative inquiry: Experience and story in qualitative research. San Francisco, CA: Jossey-Bass Publishers.

Cotton, J. L., O'Neill, B. S., \& Griffin, A. (2008). "The "name game": Affective and hiring reactions to first names. Journal of Managerial Psychology, 23, 18-39. doi:10.1108/02683940810849648

Crites, S. (1971). The narrative quality of experience. Journal of the American Academy of Religion, 39(3), 291-311. Retrieved from http://www.jstor.org/stable/1461066

Deluzain, H. E. (1996). Names and personal identity. Behind the name: The etymology and history of first names. Retrieved from http://www.behindthename.com/articles/3.php

Dewey, J. (1938). Experience and education. New York, NY: The Macmillan Co.

Greene, M. (1995). Releasing the imagination: Essays on education, the arts, and social change. San Francisco, CA: Jossey Bass.

Heilbrun, C. (1999). Women's lives: The view from the threshold. Toronto, ON: University of Toronto Press.

hooks, b. (1989). Talking back: Thinking feminist, thinking black. Boston, MA: South End Press.

Huber, J., Caine, V., Huber, M., \& Steeves, P. (2013). Narrative inquiry as pedagogy in education: The extraordinary potential of living, telling, retelling, and reliving stories of experience. Review of Research in Education, 37, 212-242. doi:10.3102/0091732X12458885

Johnson, M. (1989). Embodied Knowledge. Curriculum Inquiry, 19(4), 361-377. doi:10.2307/1179358

Kalist, D. E., \& Lee, D. Y. (2009). First names and crime: Does unpopularity spell trouble? Social Science Quarterly, 90, 39-49. doi:10.1111/j.1540-6237.2009.00601.x

Kubota, H. (2017). A narrative inquiry into the experiences of people who are homeless in Japan (Doctoral Dissertation). University of Alberta. Retrieved from https://era.library.ualberta.ca/files/cst74cq90x/Kubota_Hiroko_201709_PhD.pdf

Kubota, H., Menon, J., Redlich-Amirav, D., \& Saleh, M. (2015). A narrative conception of professional development as a nested community. LEARNing Landscapes, 9, 161-176. Retrieved from http://www.learninglandscapes.ca/index.php/learnland/article/view/751/751 
Laham, S. M., Koval, P., \& Alter, A. L. (2011). The name-pronunciation effect: Why people like Mr. Smith more than Mr. Colquhoun. Journal of Experimental Social Psychology, 48(3), 752-756. doi:10.1016/j.jesp.2011.12.002

Leake, C. (2011, February 19). Muslim 'refused job because of his name' accuses airline bosses of racism. Mail Online. Retrieved from http://www.dailymail.co.uk/news/article-1358753/Muslim-refused-jobaccuses-airline-bosses-racism.html\#ixzz4vPqQXJX3

Lopez, B. (1990). Crow and weasel. San Francisco, CA: North Point Press.

Lorde, A. (1982). Zami: A new spelling of my name-A biomythography. Freedom, CA: Crossing Press.

Lorde, A. (1984/2007). Sister outsider: Essays and speeches. New York, NY: Crossing Press.

Lugones, M. (1987). Playfulness, "world"-travelling, and loving perception. Hypatia, 2(2), 3-19. doi:10.1111/j.1527-2001.1987.tb01062.x

Mehrabian, A. (1992). The name game: The decision that lasts a lifetime. New York, NY: Signet.

Menon, J. (2015). A narrative inquiry into the experiences of South Asian girls, mothers, and teachers in curriculum making in and out of schools. Unpublished doctoral proposal. Edmonton, AB: University of Alberta.

Menon, J., Redlich-Amirav, D., Saleh, M., \& Kubota, H. (2015). Embracing lived multiplicities as beginning narrative inquirers. Creative Approaches to Research, 8(3), 80-101. Retrieved from http://creativeapproachestoresearch.net/wp-content/uploads/CAR8_3_fullissue.pdf

Nelson, H. L. (1995). Resistance and insubordination. Hypatia, 10(2), 23-40.

Nelson, T. (2009, January 15). Muhammad Ali and the origin of "What's my name?" Retrieved from http://wnst.net/nfl/muhammad-ali-and-the-origin-of-whats-my-name/

Saleh, M. (2017). Stories we live by, with, and in: A narrative inquiry into the experiences of Canadian Muslim girls and their mothers (Doctoral Dissertation). University of Alberta. Retrieved from https://era.library.ualberta.ca/files/cm326m214z/Saleh_Muna_201709_PhD.pdf

Saleh, M., Menon, J., \& Clandinin, D. J. (2014). Autobiographical narrative inquiry: Tellings and retellings. Learning Landscapes, 7(2), 271-282. Retrieved from http://www.learninglandscapes.ca/

Shakespeare, W. (1913). Romeo and Juliet. H. H. Furness (Ed.). Philadelphia, PA: J. B Lippincott Company.

van Tilburg, W. A. P., \& Igou, E. R. (2014). The impact of middle names: Middle name initials enhance evaluations of intellectual performance. European Journal of Social Psychology, 44(4), 400-411. doi:10.1002/ejsp.2026

Waheed, N. (2014). Nejma. Charleston, SC: Createspace. 


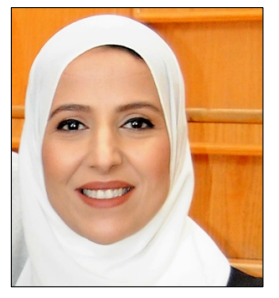

Muna Saleh recently completed her doctoral program in the Department of Elementary Education at the University of Alberta. Her two-year doctoral research, a narrative inquiry into the experiences of Canadian Muslim girls and their mothers, drew upon Muna's experiences as a Canadian Muslim woman, mother, educator, and researcher mother alongside six other Canadian Muslim women. Before her graduate studies, Muna was an elementary and secondary school teacher and leader. Muna is currently an Assistant Professor in the Faculty of Education at Concordia University of Edmonton.

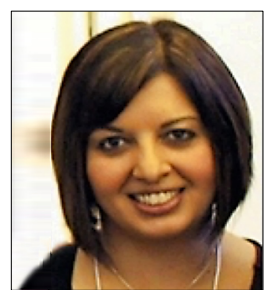

Jinny Menon is a PhD candidate at the University of Alberta and a member of the university's Centre for Research for Teacher Education and Development. For Jinny, a multiplicity of knowing, re-presenting, and sharing knowledge respectfully, is fundamental to re-stor(y)ing humane practices and understandings. Drawing upon her experiences as a lifelong learner, Jinny is currently engaging in a multiperspectival narrative inquiry into the curriculum-making experiences of South Asian girls, their mothers, and teacher in Canada.

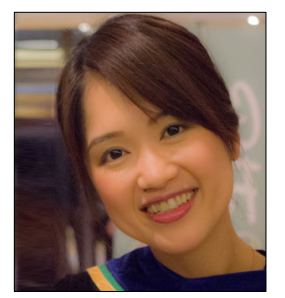

Hiroko Kubota is a post-doctoral fellow in the Faculty of Nursing at the University of Alberta, where she recently graduated with a PhD. Her doctoral dissertation is titled, "A narrative inquiry into the experiences of people who are homeless in Japan." As a nurse who studied narrative inquiry, Hiroko is interested in exploring how people who are often marginalized in society experience their health across various social, cultural, institutional, and geographical contexts and how to improve their experiences of life and health. 
